УДК 577.2:631:581.115:542.1

S. CHEBOTAR ${ }^{1}$, P. SOURDILLE ${ }^{2}$, E. PAUX ${ }^{2}$, F. BALFOURIER ${ }^{2}$, C. FEUILLET ${ }^{2}$, M. BERNARD ${ }^{2}$

${ }^{1}$ South Plant Biotechnology Centre UAAN, Ovidiopolskaya dor. 3, 65036 Odessa, Ukraine

2 INRA UMR Genetic, Diversity and Ecophysiology of Cereals (GDEC), Domaine de Crouël, 234 Avenue du Brézet, 63100 Clermont-Ferrand Cedex 2, France

\section{EVALUATION OF THE GENETIC VARIABILITY OF HOMOEOLOGOUS GROUP 3 SSRS IN BREAD WHEAT}

Thorough characterization of the genetic variability in bread wheat (Triticum aestivum L.) is important for a better improvement of this key crop and to increase cereal yield in the context of sustainable agriculture to face human needs in the next decades. To study the genetic variability of SSRs on wheat homoeologous group 3 chromosomes, we characterized 38 hexaploid and two tetraploid wheat lines using a set of 165 microsatellites that we cytogenetically assigned to the 17 deletion bins for chromosomes group 3. A comparative analysis of the genetic variability through the PIC value study, allele numbers and SSR lengths indicated that there were no statistically significant differences $(p>0.05)$ between the three chromosomes of this homoeologous group despite the fact that SSRS from chromosome $3 B$ exhibited slightly more alleles per locus compared to chromosomes $3 A$ and $3 D$ as well as slightly higher PIC values compared to chromosome $3 D$. However, there was a stronger correlation between SSR length and allele number on the short arms compared to the long arms and the correlation increased from the centromeres toward the telomeres. We did not find statistically significant differences in allele numbers and PIC values for SSRs located in more distal bins on $3 A$ and $3 B$ chromosomes. On the contrary, for chromosome $3 D$, we observed significant differences $(p<0.05)$ between the PIC values determined for SSRs assigned to deletion bin 3DL3 $0.81-1.00$ bin that is located distal compare to the more proximal region (C-3DL3-0.81). These results suggest that recombination which is higher in the telomeric regions does not contribute to increase a lot the variability of the SSRS.

C) S. CHEBOTAR, P. SOURDILLE, E. PAUX, F. BALFOURIER, C. FEUILLET, M. BERNARD, 2009
Introduction. Genetic variability in cereals and especially in hexaploid wheat is extremely extended but remains largely underexploited. Characterization of genetic variation within natural populations and among breeding lines is crucial for effective conservation and exploitation of genetic resources for crop improvement programs. Thus, their evaluation should be a major activity of germplasm centres to identify useful genetic variation and make it available to breeders. A range of methods are now available to depict and evaluate genetic resources diversity. Especially Simple Sequence Repeats (SSRs), also called microsatellites (MS), have proven to be useful for assessment of genetic variation in wheat germplasm collections $[1,2]$. SSRs are a widespread and highly abundant class of repeated DNA sequences within genomes of wheat [3-9]. They have been found to be dispersed throughout the genomes with additional clusters at heterochromatic regions $[10,11]$. Both mutation factors and indirect selective events vary according to the local recombination rate and therefore jointly influence the level of polymorphism at microsatellite loci in wheat [12]. However, we have no idea whether their genetic variation is uniform overall the genome or located in specific regions (coding vs non-coding regions), and if it also varies along the chromosomes. One way to answer this question would be to study the genetic variability of SSRs distributed all over a chromosome and compare it according to their cytogenetical and/or physical position.

Recent progress in wheat genomics has made possible the elaboration of wheat chromosome-specific BAC libraries [13-15]. Moreover, the International Wheat Genome Sequencing Consortium (IWGSC, http://www.wheatgenome.org) established in January 2005, aims at the construction of an accurate, sequence-ready physical map of the hexaploid wheat genome (cv. Chinese Spring) which is anchored to the genetic map. In order to have a model to study the structure, function and evolution of the wheat genome, a physical map of wheat chromosome $3 \mathrm{~B}$ is currently under construction [16]. Chromosome 3B is $995 \mathrm{Mb}$ in length [17], which represents about $5.86 \%$ of the nuclear genome of bread wheat $(16.974 \mathrm{Mb} / 1 \mathrm{C})$ [18]. It also shows a wide range of C-banding patterns [19]. Moreover, gene density is higher at its ends $[20-22]$, and comparisons with chromosomes from other related species indicate that it is the most conserved in gene content and order [23]. 
Table 1

Name and country of origin of the wheat cultivars tested. (Durum wheats are indicated with *)

\begin{tabular}{ll}
\hline \multicolumn{1}{c}{$\begin{array}{c}\text { Country } \\
\text { of origin }\end{array}$} & \multicolumn{1}{c}{ Cultivars } \\
\hline $\begin{array}{l}\text { Afghanistan } \\
\text { Australia }\end{array}$ & A4 (748) \\
Belgium & Zurore (1110) \\
Brazil & Cotipora (2353) \\
Canada & Glenlea (3358) \\
China & Chinese Spring \\
Germany & Opal (5486) \\
Spain & Xeres* (7657) \\
Finland & Hopea (9048) \\
France & Apache (13481), Arche (964), Courtot \\
& (2358), Eureka (2830), Magnif 27 \\
& (4503), OxC37, Ornicar (13471), Pernel \\
& S681), Récital (6027), Renan (6086), \\
& Soisson (6607), Thésée (6932), V23, \\
Hungary & Goboculm \\
India & NP120 (5308) \\
Israel & M708 (4482) \\
Italy & Frumento Cupo* (3173) \\
Japan & Nyu Bay (5399) \\
Korea & Seu Seun 27 (6529) \\
Libanon & Miskaagani (4874) \\
Mexico & W7984, Bob White, Opata (13811), Pitic \\
& 62 (5748) \\
Nepal & Chyamtang (2171) \\
Portugal & Mocho de Espiga Branca (4901) \\
Russia & Bezostaya 1 (1341), Chortandinka (2153) \\
Turkey & Coppadra (2330) \\
Yugoslavia & Balkan (1192) \\
\hline &
\end{tabular}

In addition, chromosome 3B also carries many genes of agronomical interest such as resistance genes [24-26], pre-harvest sprouting tolerance genes [27] as well as numerous enzyme-coding genes (for a review, see [28]). Chromosome 3B also exhibits internal as well as external duplications according to content, distribution, and comparative-genome relationship analyzes of expressed sequence tags (ESTs) [23].

The purposes of the present study were: 1) to evaluate the variability of wheat SSRs distributed throughout the chromosomes from homoeologous group 3 (3A, 3B and 3D) using a set of lines covering a large part of the existing genetic variability; 2) to compare the variability at the distal part of chromosome arms vs pericentromeric regions for $3 \mathrm{~A}$, $3 \mathrm{~B}$ and $3 \mathrm{D}$ chromosomes.
Materials and methods. Plant material. A total of 40 wheat varieties (38 bread and two durum wheats, Table 1) were used to analyze the genetic variability of SSRs. These lines were selected according to their geographical origins, growth habits (winter or spring type), date of release (landraces, old or recent cultivars) and data on neutral polymorphism based on a set of 42 microsatellite loci, one per chromosome arm [29]. The lines covered $92 \%$ of the world genetic variability based on the evaluation of a core collection [30]. This panel also included the parental lines of several genetic mapping populations. Seeds were obtained from the Centre of Biological Resources on Cereal Crops, INRA-Clermont-Ferrand. Moreover, the set of the three nulli-tetrasomic (NT) and six ditelosomic (DT) wheat lines from homoeologous group 3 ([31, 32]; kindly provided by Dr Steve Reader, John Innes Centre, United Kingdom) was used for chromosomal assignment of markers. A more accurate location of the SSRs on the chromosomes was obtained using a set of respectively four, five and three deletion lines from chromosomes 3A (3AS-4, 3AS-2, 3AL-3, 3AL-5), 3B (3BS-8, 3BS-9, 3BS-1, 3BL-10, 3BL-7) and 3D (3DS-6, 3DS-3, 3DL-3) [33]. Between five and 10 seeds from self-pollinated ears of each lines were sown for further DNA extraction.

DNA extraction, PCR amplification and SSR detection. DNA was extracted from fresh leaves ground in liquid nitrogen using a CTAB protocol [34]. A set of 41, 76 and 48 SSRs was selected from Graingenes data [35] and Somers et al. [9] for chromosomes $3 \mathrm{~A}, 3 \mathrm{~B}$ and $3 \mathrm{D}$, respectively. SSR order along the chromosomes that is presented in the tables and diagrams was derived from the maps that indicated in Graingenes and in [9] and according to our assignment using deletion bin and ditelosomic lines. PCR reactions using the M13 protocol were carried out as described in [36] with an annealing temperature of $60^{\circ} \mathrm{C}$ for 30 cycles ( $30 \mathrm{sec}$ $94{ }^{\circ} \mathrm{C}, 30 \sec 60^{\circ} \mathrm{C}, 30 \sec 72^{\circ} \mathrm{C}$ ) and $56^{\circ} \mathrm{C}$ for 8 cycles. Amplification products were visualized using an ABI PRISM ${ }^{\circledR} 3100$ Genetic Analyzer (Applied Biosystems). Finally, fragment sizes were calculated using Genescan and Genotyper softwares (Applied Biosystems), where different alleles are represented by different amplification sizes for tandem repeats. Two alleles were considered identical when they showed the same fragment size. 
Estimation of PIC values and statistical analyses. Allelic polymorphism information content (PIC) values were calculated in each case using the formula $\mathrm{PIC}=1-\sum(\mathrm{P} i)^{2}$, where $\mathrm{P} i$ is the proportion of the population carrying the $i^{\text {th }}$ allele, calculated for each SSR locus [37]. Comparative analyses of SSR genetic variability overall the chromosomes were computed as follows. For better revealing variability tendencies for microsatellites distributed along chromosomes a simple standard procedure of 5 points smoothing with equal weights for each point involved was applied, according to the usefulness of sequences smoothing procedure recommended by Tukey [38]. Linear regressions between the length and allele number of microsatellites were also calculated. For narrowness of dependencies, coefficients of determination were computed as $\mathrm{R}^{2}$. Finally, to build up profiles of local correlation between length (define as the number of nucleotides forming the microsatellite $X$ the number of repeats according values given in Graingenes database [35] and allele number, a procedure of point-by-point calculation was used («moving correlation»). Every consequent coefficient was based on 11 points with centrum in point 6 . Using these conditions $(\mathrm{df}=9)$, every single coefficient with level equal or greater than 0.6 is significant at $\mathrm{p}=0.05$. At shorter bases $(<11$ points), problems with significance may occur while using too long bases $(>11)$ leads to over-losses of information in the two distal parts of chromosomes.

Significance of differences between allele numbers, microsatellite lengths and the PIC values for microsatellites located on homoeologous group 3 chromosomes, on the short and long arms, and those assigned to deletion bins was estimated for this Mann-Whitney U-test [39] the method of nonparametric statistics was applied.

Results. Genetic variability of the SSRs. Respectively 41,76 and 48 SSRs were evaluated for chromosomes 3A, 3B and 3D. Results are given in detail in Tables 2-4. This represented a density of one marker every $2.97,1.95$ and $1.65 \mathrm{cM}$ corresponding to one marker every $20.2,13.1$ and $16.1 \mathrm{Mb}$ respectively, which was not statistically different between the different genomes. The number of alleles varied from one (several loci not polymorphic in the plant material tested, but assigned to homoeologous group 3 chromosomes using aneuploid lines) to 21 alleles for loci Xgpw4431-3B and
Xcfa2134-3A. Respectively 276, 524 and 290 alleles were scored for chromosomes $3 \mathrm{~A}, 3 \mathrm{~B}$ and $3 \mathrm{D}$, which corresponded to means of $6.73,6.89$ and 6.04 alleles/locus. The PIC values for the SSRs were similar and not statistically different between the three chromosomes from homoeologous group 3 . They ranged from 0 to 0.91 for chromosome $3 \mathrm{~A}$, from 0 to 0.93 for chromosome $3 \mathrm{~B}$ and from 0 to 0.93 for chromosome $3 \mathrm{D}$ with respective means of $0.61,0.58$ and 0.54 .

Concerning the type of repeats, we found that dinucleotide repeats were the most abundant class of microsatellite markers mapped on chromosomes from homoeologous group 3 of T. aestivum. About $73.2 \%$ of the tested SSRs located on chromosome $3 \mathrm{~A}$ have dinucleotide motif ( 25 simple and 5 compound) while this proportion was about $71 \%$ (40 simple and 14 compound) and $75 \%$ (33 simple and 3 compound) for microsatellites from chromosomes $3 \mathrm{~B}$ and $3 \mathrm{D}$ respectively (Table $2-4$ ). This was not unexpected since most of the microsatellites that have been genetically mapped until now are mainly issued from enriched or screened libraries using dinucleotide motifs for enrichment $[3,8,40]$. Only one microsatellite motif $(\mathrm{AT})_{n}$ and no microsatellite motifs $(\mathrm{GC})_{n}$ were observed, probably because these motifs were rarely used for library enrichment or screening and also because they are difficult to isolate due to the formation of hairpin loops during the enrichment steps. Here, for dinucleotide motifs, the average number of alleles ranged from 6.25 for (GT/CA $)_{n}$ to 8.65 for $(\mathrm{GA} / \mathrm{CT})_{n}$. For trinucleotide and tetranucleotide motifs, the average numbers of alleles were respectively 3.1 and 4.6 which was significantly lower than for dinucleotide motifs.

Variability of microsatellite loci along chromosome 3A. Between one and 14 SSR loci have been assigned to the six deletion bins from chromosome 3A (Table 2). Especially, four SSRs loci were assigned to deletion bin 3 AS2 $-0.23-0.45$ while none were assigned to this bin previously [41, 42]. The allele number for the 41 microsatellites which were located on chromosome $3 \mathrm{~A}$ ranged from one for the three loci Xgpw7031-3A, Xgpw7553-3A and $X g p w 7467-3 A$ to 21 for the locus Xcfa2134-3A. The PIC values ranged from 0 to 0.91 (mean 0.61 ) while SSR length varied from 14 to $156 \mathrm{bp}$. We analyzed the variation of allele numbers, microsatellite lengths and PIC values along this chromosome 
S. Chebotar, P. Sourdille, E. Paux, F. Balfourier, C. Feuillet, M. Bernard

Table 2

Microsatellite markers from chromosome 3A evaluated for genetic variability and PIC values

\begin{tabular}{|c|c|c|c|c|c|}
\hline Part of chromosome and loci & Motif & Length & $\begin{array}{l}\text { Numbers } \\
\text { of alleles }\end{array}$ & PIC & $\begin{array}{l}\text { Fragment size } \\
\text { in 'CS' } \\
\text { ( in bp) }\end{array}$ \\
\hline \multicolumn{6}{|l|}{$3 \mathrm{AS} 4-0.45-1.0$} \\
\hline Xgpw7031 & $(\mathrm{AGC})_{6}$ & 18 & 1 & 0,00 & 192 \\
\hline Xwmc532 & $(\mathrm{GA})_{5} /(\mathrm{GA})_{11}$ & 32 & 7 & 0,80 & 195 \\
\hline Xbarc45 & $(\mathrm{TAA})_{10}$ & 30 & 7 & 0,54 & 202 \\
\hline Xgpw4074 & $(\mathrm{CT})_{15}$ & 30 & 4 & 0,63 & 261 \\
\hline Xgpw2142 & $(\mathrm{GT})_{40}$ & 80 & 5 & 0,36 & 266 \\
\hline Xgwm2 & $(\mathrm{CA})_{18}$ & 36 & 9 & 0,72 & 143 \\
\hline Xwmc505 & $(\mathrm{CA})_{31}$ & 62 & 5 & 0,69 & 127 \\
\hline Xgpw4221 & $(\mathrm{TC})_{12}$ & 24 & 4 & 0,43 & 262 \\
\hline \multicolumn{6}{|l|}{$3 \mathrm{AS} 2-0.23-0.45$} \\
\hline Xgwm674 & $(\mathrm{CT})_{16} / \mathrm{CCC} /(\mathrm{GT})_{4}$ & 43 & 5 & 0,51 & 184 \\
\hline Xcfa2234 & (CA) 17 & 34 & 3 & 0,47 & 161 \\
\hline Xgpw5216 & $(\mathrm{GA})_{21.5} /(\mathrm{CATG})_{7}$ & 71 & 3 & 0,53 & 355 \\
\hline Xgpw3223 & $(A G)_{27}$ & 54 & 11 & 0,88 & 298 \\
\hline \multicolumn{6}{|l|}{$\mathrm{C}-3 \mathrm{AS} 3-0.23$} \\
\hline Xwmc664 & $(\mathrm{GA})_{44}$ & 88 & 15 & 0,89 & 179 \\
\hline \multicolumn{6}{|l|}{ C-3AL3 -0.42} \\
\hline Xgpw8038 & $(\mathrm{TC})_{19}$ & 38 & 5 & 0,69 & 170 \\
\hline Xgpw 7553 & $(\mathrm{CTG})_{6}$ & 18 & 1 & 0,00 & 150 \\
\hline Xgpw 7467 & $(\mathrm{CAG})_{16} /(\mathrm{CAA})_{30} /(\mathrm{CAG})_{6}$ & 156 & 1 & 0,00 & 297 \\
\hline Xgpw5007 & $(\mathrm{CT})_{23}$ & 46 & 8 & 0,84 & 199 \\
\hline \multicolumn{6}{|l|}{$3 \mathrm{AL} 3-0.42-0.78$} \\
\hline Xwmc 428 & $(\mathrm{CA})_{25} /(\mathrm{CA})_{4}$ & 58 & 8 & 0,67 & 276 \\
\hline Xwmc153 & $(\mathrm{GT})_{20} /(\mathrm{GT})_{18} /(\mathrm{GT})_{11}$ & 98 & 10 & 0,77 & 201 \\
\hline Xgpw2169 & $(\mathrm{TG})_{21}$ & 42 & 7 & 0,73 & 330 \\
\hline Xgpw5042 & $(\mathrm{CA})_{9}$ & 18 & 6 & 0,67 & 191 \\
\hline Xbarc67 & $(\text { GATA })_{9} /(\text { GATA })_{3}$ & 48 & 5 & 0,44 & 122 \\
\hline Xwmc627 & $(\mathrm{GA})_{9}$ & 18 & 8 & 0,75 & 134 \\
\hline Xcfa2134 & $(\mathrm{CT})_{23}$ & 46 & 21 & 0,91 & 258 \\
\hline Xgpw8072 & $(\mathrm{CG})_{7}$ & 14 & 5 & 0,72 & 172 \\
\hline Xgpw2266 & $(\mathrm{CA})_{16}$ & 32 & 16 & 0,84 & 280 \\
\hline Xgpw4352 & $(\mathrm{GT})_{15}$ & 30 & 5 & 0,59 & 275 \\
\hline \multicolumn{6}{|l|}{$3 \mathrm{AL} 5-0.78-1.00$} \\
\hline Xgwm 480 & $(\mathrm{CT})_{16}(\mathrm{CA})_{13}$ & 58 & 10 & 0,60 & 189 \\
\hline Xwmc264 & $(\mathrm{GA})_{16}$ & 32 & 9 & 0,78 & 151 \\
\hline Xgpw7219 & $(\mathrm{AGG})_{7}$ & 21 & 3 & 0,52 & 150 \\
\hline Xwmc594 & $(\mathrm{GA})_{43}$ & 86 & 14 & 0,91 & 193 \\
\hline Xwmc559 & $(\mathrm{GT})_{16} /(\mathrm{GT})_{14} /(\mathrm{GT})_{10}$ & 80 & 8 & 0,82 & 277 \\
\hline Xcfa2193 & $(\mathrm{GT})_{12}$ & 24 & 8 & 0,83 & 228 \\
\hline Xgpw 7643 & $(\mathrm{CAG})_{9.7} /(\mathrm{CAG})_{5} /(\mathrm{GCA})_{24}$ & 116,1 & 3 & 0,52 & 374 \\
\hline Xgpw7663 & $(\mathrm{GGC})_{5}$ & 15 & 2 & 0,23 & 314 \\
\hline Xcfa2170 & $(\mathrm{GA})_{31}$ & 62 & 6 & 0,65 & 219 \\
\hline Xgpw307 & $(\mathrm{CA})_{21}$ & 42 & 5 & 0,71 & 148 \\
\hline Xgpw5271 & $(\mathrm{AG})_{12}$ & 24 & 5 & 0,64 & 255 \\
\hline Xcfa2183 & $(\mathrm{CA})_{26}$ & 52 & 7 & 0,68 & 178 \\
\hline Xcfa2037 & $(\mathrm{CA})_{23}$ & 46 & 4 & 0,38 & 196 \\
\hline Xwmc 169 & $(\mathrm{CA})_{25}$ & 50 & 7 & 0,62 & 127 \\
\hline
\end{tabular}


Table 3

Microsatellite markers from chromosome 3B evaluated for genetic variability and PIC values

\begin{tabular}{|c|c|c|c|c|c|}
\hline $\begin{array}{c}\text { Part of chromosome } \\
\text { and loci }\end{array}$ & Motif & Length & $\begin{array}{l}\text { Numbers } \\
\text { of alleles }\end{array}$ & PIC & $\begin{array}{l}\text { Fragment } \\
\text { size in 'CS' } \\
\quad \text { ( in bp) }\end{array}$ \\
\hline \multicolumn{6}{|l|}{$3 \mathrm{BS} 8-0.78-1.00$} \\
\hline Xgpw8020 & $(\mathrm{CT})_{8}$ & 16 & 2 & 0,50 & null \\
\hline Xgpw7757 & $(\mathrm{GCC})_{6}$ & 18 & 3 & 0,53 & 243 \\
\hline Xbarc 75 & $(\mathrm{TAG})_{2} /(\mathrm{TAGA})_{5}$ & 26 & 4 & 0,58 & 125 \\
\hline Xbarc180 & $(\mathrm{ATT})_{21}$ & 63 & 8 & 0,77 & 212 \\
\hline Xbarc 147 & $(\mathrm{CA})_{14}$ & 28 & 13 & 0,65 & 177 \\
\hline Xgwm 493 & $(\mathrm{CA})_{43}$ imperfect & 86 & 12 & 0,82 & 212 \\
\hline Xgpw3156 & (C) 17 & 17 & 5 & 0,67 & 130 \\
\hline Xgwm389 & $(\mathrm{CT})_{14} /(\mathrm{GT})_{16}$ & 60 & 11 & 0,87 & 131 \\
\hline Xwmc623 & $(\mathrm{GA})_{31}$ & 62 & 15 & 0,86 & 208 \\
\hline Xgpw7031 & $(\mathrm{AGC})_{6}$ & 18 & 1 & 0,00 & 198 \\
\hline Xgpw3092 & $(\mathrm{AG})_{15}$ & 30 & 11 & 0,78 & 200 \\
\hline \multicolumn{6}{|l|}{$3 \mathrm{BS} 9-0.57-0.78$} \\
\hline Xcfa2191 & $(\mathrm{TCCC})_{4}$ & 16 & 2 & 0,10 & 179 \\
\hline$X g w m 533$ & $(\mathrm{CT})_{18} /(\mathrm{CA})_{20}$ & 76 & 11 & 0,76 & 172 \\
\hline Xbarc092 & (TTA) 11 & 33 & 3 & 0,38 & 169 \\
\hline$X c f a 2226$ & $\left(\mathrm{GCT}_{6}\right.$ & 18 & 4 & 0,49 & 192 \\
\hline Xgpw7774 & $(\mathrm{AGC})_{8}$ & 24 & 3 & 0,49 & 130 \\
\hline Xgpw 7452 & $(\mathrm{CA})_{23}$ & 46 & 7 & 0,70 & 136 \\
\hline$X w m c 231$ & $(\mathrm{GA})_{10} /(\mathrm{GT})_{8}$ & 36 & 7 & 0,75 & 247 \\
\hline Xgpw4146 & $(\mathrm{TG})_{15}$ & 30 & 7 & 0,62 & null \\
\hline Xwmc43 & $(\mathrm{GT})_{14}$ & 28 & 4 & 0,27 & 342 \\
\hline Xgwm284 & $(\mathrm{GA})_{17}$ & 34 & 6 & 0,80 & 138 \\
\hline Xgwm566 & $(\mathrm{CA})_{21} /(\mathrm{GA})_{2} /(\mathrm{TA})_{8}$ & 62 & 8 & 0,79 & 148 \\
\hline barc068 & $(\mathrm{TC})_{3} /(\text { TATC })_{6} /(\text { TATC })_{7}$ & 30 & 6 & 0,76 & 151 \\
\hline$X w m c 777$ & $(\mathrm{GA})_{36}$ & 72 & 7 & 0,53 & 157 \\
\hline \multicolumn{6}{|l|}{$3 \mathrm{BS} 1-0.33-0.57$} \\
\hline Xgwm 77 & $(\mathrm{CA})_{10} /(\mathrm{GA})_{40}$ & 100 & 10 & 0,53 & 168 \\
\hline Xwmc 78 & $(\mathrm{CA})_{18}$ & 36 & 9 & 0,77 & 279 \\
\hline$X w m c 540$ & $(\mathrm{GT})_{9}$ & 18 & 2 & 0,22 & 239 \\
\hline Xwmc533 & $(\mathrm{CA})_{20}$ & 40 & 1 & 0,00 & 150 \\
\hline$X w m c 762$ & $(\mathrm{GA})_{34}$ & 68 & 15 & 0,87 & 140 \\
\hline Xgpw1120 & $(\mathrm{CA})_{24}$ & 48 & 8 & 0,85 & 265 \\
\hline \multicolumn{6}{|l|}{$\mathrm{C}-3 \mathrm{BS} 1-0.33$} \\
\hline Xgpw4207 & $(\mathrm{TG})_{12}$ & 24 & 6 & 0,60 & 368 \\
\hline Xwmc612 & $(\mathrm{GA})_{40}$ & 80 & 15 & 0,88 & 302 \\
\hline Xwmc274 & $(\mathrm{GAAAA})_{2}$ & 45 & 1 & 0,00 & 153 \\
\hline Xwmc625 & $(\mathrm{CT})_{10} /(\mathrm{CT})_{8}$ & 36 & 11 & 0,59 & 141 \\
\hline Xgpw3134 & $(\mathrm{GA})_{19}$ & 38 & 6 & 0,77 & 130 \\
\hline Xwmc544 & $(\mathrm{CA})_{14} /(\mathrm{CA})_{10}$ & 48 & 7 & 0,59 & 398 \\
\hline Xgpw 4225 & (TC) 26 & 52 & 20 & 0,93 & 202 \\
\hline Xgwm 285 & $(\mathrm{GA})_{27}$ & 54 & 17 & 0,88 & 241 \\
\hline \multicolumn{6}{|l|}{ C-3BL10 - 0.50-0.63 } \\
\hline Xgpw1145 & $(\mathrm{CA})_{19}$ & 38 & 4 & 0,38 & 187 \\
\hline$X w m c 1$ & $(\mathrm{CT})(\mathrm{CA}) /(\mathrm{CA})_{14}$ & 32 & 6 & 0,84 & 173 \\
\hline Xgpw3254 & $(\mathrm{AG})_{13}$ & 26 & 7 & 0,75 & 250 \\
\hline Xgwm 376 & $(\mathrm{CA})_{16} /(\mathrm{GA})_{22}$ & 76 & 8 & 0,80 & 158 \\
\hline Xgpw2266 & $(\mathrm{CA})_{16}$ & 32 & 1 & 0,00 & 280 \\
\hline
\end{tabular}


Continued Table 3

\begin{tabular}{|c|c|c|c|c|c|}
\hline $\begin{array}{c}\text { Part of chromosome } \\
\text { and loci }\end{array}$ & Motif & Length & $\begin{array}{l}\text { Numbers } \\
\text { of alleles }\end{array}$ & PIC & $\begin{array}{c}\text { Fragment } \\
\text { size in 'CS' } \\
\text { ( in bp) }\end{array}$ \\
\hline Xgpw 7220 & $(\mathrm{AG})_{7}$ & 14 & 2 & 0,43 & 160 \\
\hline Xgpw7816 & $(\mathrm{CAC})_{8.7}$ & 26,1 & 4 & 0,34 & 275 \\
\hline Xgpw4078 & (TG) 16.5 & 33 & 7 & 0,71 & 251 \\
\hline Xwmc307 & $(\mathrm{GT})_{8} /(\mathrm{GA})_{13}$ & 42 & 6 & 0,76 & 166 \\
\hline Xgpw4034 & $(\mathrm{GT})_{16}$ & 32 & 7 & 0,73 & 246 \\
\hline Xgpw1107 & $(\mathrm{GA})_{19}$ & 38 & 5 & 0,70 & 148 \\
\hline Xgpw7805 & $(\mathrm{CGG})_{7.3} /(\mathrm{TCC})_{4}$ & 33,9 & 1 & 0,00 & 184 \\
\hline Xwmc527 & $(\mathrm{CA})_{15} /(\mathrm{GA})_{20}$ & 70 & 9 & 0,72 & 397 \\
\hline Xgpw3053 & (TG) 10 & 20 & 5 & 0,70 & 313 \\
\hline Xwmc291 & $(\mathrm{GT})_{26}$ & 52 & 7 & 0,82 & 245 \\
\hline Xgpw7467 & $(\mathrm{CAG})_{16} /(\mathrm{CAA})_{30} /(\mathrm{CAG})_{6}$ & 156 & 1 & 0,00 & 300 \\
\hline Xgpw4451 & $(\mathrm{CT})_{20}$ & 40 & 2 & 0,15 & 152 \\
\hline$X w m c 326$ & $(\mathrm{CT})_{16}$ & 32 & 13 & 0,88 & 204 \\
\hline Xwmc632 & $(\mathrm{GA})_{38}$ & 76 & 15 & 0,90 & 198 \\
\hline Xgpw7335 & $(\mathrm{GCC})_{4}$ & 12 & 1 & 0,00 & 384 \\
\hline \multicolumn{6}{|l|}{$3 \mathrm{BL} 10-0.50-0.63$} \\
\hline Xgpw4497 & $(\mathrm{TC})_{37} /(\mathrm{CA})_{24}$ & 122 & 13 & 0,91 & 193 \\
\hline Xgpw4431 & $(\mathrm{TC})_{24}$ & 48 & 21 & 0,93 & 280 \\
\hline Xbarc 164 & $(\mathrm{ATT})_{18}$ & 54 & 11 & 0,83 & 222 \\
\hline Xwmc418 & $(\mathrm{GT})_{13}$ & 26 & 1 & 0,00 & 266 \\
\hline Xgpw4143 & $(\mathrm{TC})_{12}$ & 24 & 5 & 0,68 & 245 \\
\hline \multicolumn{6}{|l|}{$3 \mathrm{BL} 7-0.63-1.0$} \\
\hline$X c f d 283$ & $(\mathrm{CCCA})_{3}$ & 12 & 2 & 0,38 & 252 \\
\hline Xgpw4505 & $(\mathrm{TC})_{17}$ & 34 & 7 & 0,78 & 176 \\
\hline Xgpw8064 & $(\mathrm{AT})_{8}$ & 16 & 2 & 0,44 & 149 \\
\hline Xgpw1025 & $(\mathrm{CA})_{48}$ & 96 & 9 & 0,75 & 181 \\
\hline$X c f a 2170$ & $(\mathrm{GA})_{31}$ & 62 & 4 & 0,53 & 176 \\
\hline Xbarc 77 & $(\mathrm{ATCT})_{6} /(\mathrm{ATCT})_{18}$ & 96 & 12 & 0,88 & 226 \\
\hline Xgpw7586 & $(\mathrm{GTG})_{4}$ & 12 & 1 & 0,00 & 348 \\
\hline Xgpw 7213 & $(\mathrm{CGCCG})_{3}$ & 15 & 2 & 0,40 & 330 \\
\hline Xgpw5007 & $(\mathrm{CT})_{23}$ & 46 & 4 & 0,38 & 165 \\
\hline Xgpw5271 & $(\mathrm{GA})_{10} /(\mathrm{GA})_{12}$ & 44 & 1 & 0,00 & 222 \\
\hline Xgpw7088 & $(\mathrm{CATG})_{7} /(\mathrm{GCATG})_{5}$ & 53 & 2 & 0,49 & 207 \\
\hline Xgwm 247 & $(\mathrm{GA})_{24}$ & 48 & 13 & 0,90 & 180 \\
\hline Xgwm340 & $(\mathrm{GA})_{26}$ & 52 & 15 & 0,89 & 128 \\
\hline
\end{tabular}

using the standard method of moving means (see M\&Ms; Fig. 1, a). The three curves followed similar profiles on the short arm of the chromosome as well as on the distal part of the long arm (deletion bin 3AL5 - 0.78-1.00). On the contrary, the SSR length curve showed an opposite profile compared to the other two along the deletion bins C-3AL3 0.42 and 3AL3 $-0.42-0.78$ (slanting arrows on Fig. 1, a). Moreover, these two bins showed different profiles: in the former, SSR length was high compared to the level of polymorphism they revealed while in the latter, SSRs were short but revealed a high level of polymorphism. In order to further study the effect of SSR length on allele number, the diagrams of moving correlation between these two parameters at microsatellite loci along the chromosome 3A were built (Fig. 2,a). We observed that the correlation was high $(r>0.4)$ in the middle of each arm while it was lower near the telomere. The correlation between SSR length and allele number was negative in bin C-3AL3 0.42 contrary to the distal part of bin 3AL3 $0.42-0.78$ where correlation was highly positive. This suggests that the correlation between length 
Microsatellite markers from chromosome 3D evaluated for genetic variability and PIC values

\begin{tabular}{|c|c|c|c|c|c|}
\hline $\begin{array}{c}\text { Part of chromosome } \\
\text { and loci }\end{array}$ & Motif & Length & $\begin{array}{l}\text { Numbers } \\
\text { of alleles }\end{array}$ & PIC & $\begin{array}{l}\text { Fragment } \\
\text { size in 'CS' } \\
\text { ( in bp) }\end{array}$ \\
\hline \multicolumn{6}{|l|}{$3 \mathrm{DS} 6-0.55-1.00$} \\
\hline$X c f d 35$ & $(\mathrm{GT})_{13} /(\mathrm{CT})_{20}$ & 66 & 7 & 0,78 & 207 \\
\hline Xgwm 161 & $(\mathrm{CT})_{15}$ & 30 & 7 & 0,64 & 172 \\
\hline$X c f d 141$ & $(\mathrm{TCAA})_{4}$ & 16 & 2 & 0,11 & 172 \\
\hline$X c f d 55$ & $(\mathrm{GT})_{23}$ & 46 & 8 & 0,80 & 295 \\
\hline Xgpw7553 & $(\mathrm{CTG})_{6}$ & 18 & 2 & 0,05 & 152 \\
\hline Xgpw5248 & $(\mathrm{CA})_{41.5}$ & 83 & 5 & 0,58 & 234 \\
\hline Xgpw5213 & $(\mathrm{AG})_{23}$ & 46 & 15 & 0,91 & 294 \\
\hline$X w m c 43$ & $(\mathrm{GT})_{14}$ & 28 & 4 & 0,17 & 350 \\
\hline Xcfd79 & $(\mathrm{GA})_{26}$ & 52 & 8 & 0,80 & 280 \\
\hline Xgpw4074 & $(\mathrm{CT})_{15}$ & 30 & 4 & 0,62 & 259 \\
\hline$X c f d 70$ & $(\mathrm{CA})_{19}$ & 38 & 8 & 0,74 & 190 \\
\hline$X c f d 34$ & $(\mathrm{GGA})_{5} /(\mathrm{G})_{13}$ & 28 & 3 & 0,58 & null \\
\hline Xgpw5216 & $(\mathrm{GA})_{2.5} /(\mathrm{CATG})_{7}$ & 32 & 6 & 0,72 & 390 \\
\hline Xwmc533 & $(\mathrm{CA})_{20}$ & 40 & 7 & 0,79 & 167 \\
\hline \multicolumn{6}{|l|}{$3 \mathrm{DS} 3-0.24-0.55$} \\
\hline Xgpw5067 & $(\mathrm{GA})_{17}$ & 34 & 3 & 0,55 & 279 \\
\hline Xgpw4163 & $(\mathrm{AGA})_{4} /(\mathrm{TC})_{21}$ & 54 & 9 & 0,85 & 409 \\
\hline Xgpw333 & $(\mathrm{GT})_{13}$ & 26 & 4 & 0,37 & 287 \\
\hline Xgpw5104 & $(\mathrm{CT})_{24}$ & 48 & 9 & 0,84 & 188 \\
\hline Xgwm341 & $(\mathrm{CT})_{26}$ & 52 & 14 & 0,89 & 170 \\
\hline \multicolumn{6}{|l|}{ C-3DL3 -0.81} \\
\hline Xgpw1168 & $(\mathrm{GGC})_{5}$ & 15 & 2 & 0,05 & 205 \\
\hline Xgpw5166 & $(\mathrm{GA})_{19.5}$ & 39 & 5 & 0,59 & 155 \\
\hline Xgpw 7467 & $(\mathrm{CAG})_{16} /(\mathrm{CAA})_{30} /(\mathrm{CAG})_{6}$ & 156 & 2 & 0,10 & 323 \\
\hline Xgpw3109 & $(\mathrm{AG})_{19}$ & 38 & 9 & 0,84 & 231 \\
\hline Xgpw2266 & $(\mathrm{CA})_{16}$ & 32 & 1 & 0,00 & 236 \\
\hline Xgpw5042 & $(\mathrm{CA})_{9}$ & 18 & 3 & 0,27 & 173 \\
\hline Xgwm52 & $(\mathrm{GT})_{4} / \mathrm{AT} /(\mathrm{GT})_{20}$ & 50 & 7 & 0,75 & 170 \\
\hline Xgpw1062 & $(\mathrm{CA})_{16}$ & 32 & 1 & 0,00 & 203 \\
\hline Xgpw4451 & $(\mathrm{CT})_{20}$ & 40 & 5 & 0,48 & 166 \\
\hline Xgpw1149 & $(\mathrm{CA})_{48}$ & 96 & 4 & 0,50 & 130 \\
\hline Xgpw8116 & $(\text { ATATA })_{8}$ & 40 & 1 & 0,00 & 189 \\
\hline Xcfd152 & $(\mathrm{TC})_{24}$ & 48 & 10 & 0,80 & 308 \\
\hline Xgpw 7586 & $(\mathrm{GTG})_{4}$ & 12 & 2 & 0,06 & 393 \\
\hline Xgpw7663 & $(\mathrm{GGC})_{5}$ & 15 & 2 & 0,05 & 327 \\
\hline Xgpw5123 & $(\mathrm{CT})_{18.5}$ & 37 & 7 & 0,79 & 257 \\
\hline Xgpw7643 & $(\mathrm{CAG})_{9.7} /(\mathrm{CAG})_{5} /(\mathrm{GCA})_{24}$ & 116,1 & 4 & 0,14 & 391 \\
\hline Xcfd127 & $(\mathrm{GCC})_{6}$ & 18 & 2 & 0,06 & 170 \\
\hline Xgwm645 & $(\mathrm{CT})_{23}$ imperfect & 46 & 11 & 0,88 & 148 \\
\hline Xgwm383 & $(\mathrm{GT})_{27}$ & 54 & 6 & 0,76 & 215 \\
\hline \multicolumn{6}{|l|}{$3 \mathrm{DL} 3-0.81-1.00$} \\
\hline$X c f d 211$ & $(\mathrm{GA})_{17}$ & 34 & 3 & 0,61 & 295 \\
\hline$X c f d 223$ & $(\mathrm{TG})_{18}$ & 36 & 7 & 0,73 & 188 \\
\hline Xgpw4136 & $(\mathrm{CT})_{52}$ & 104 & 11 & 0,85 & 262 \\
\hline Xgpw5064 & $(\mathrm{GA})_{17}$ & 34 & 14 & 0,90 & 364 \\
\hline Xgpw5067 & $(\mathrm{GA})_{17}$ & 34 & 5 & 0,73 & 274 \\
\hline Xgpw294 & $(\mathrm{CA})_{31}$ & 62 & 8 & 0,76 & 116 \\
\hline
\end{tabular}


Continued Table 4

\begin{tabular}{ll|c|c|c|c}
\hline $\begin{array}{c}\text { Part of chromosome } \\
\text { and loci }\end{array}$ & Motif & Length & $\begin{array}{c}\text { Numbers } \\
\text { of alleles }\end{array}$ & $\begin{array}{c}\text { Fragment } \\
\text { size in 'CS' } \\
\text { in bp })\end{array}$ \\
\hline Xgpw5001 & (GA) 18 & 36 & 6 & 0,72 & 212 \\
Xgpw5263 & (TC)36 & 72 & 4 & 0,46 & 306 \\
Xgpw5235 & (GA)36 & 72 & 3 & 0,46 & 305 \\
Xcfd9 & (TC)29 & 58 & 20 & 0,93 & 259 \\
\hline
\end{tabular}

(linked to the number of repeats) and polymorphism which is generally admitted is not systematic.

Variability of microsatellite loci along chromosome $3 \boldsymbol{B}$. Between five and 20 SSR loci were assigned to the six deletion bins of chromosome 3B (Table 3). The allele number for the 76 microsatellite loci assigned to chromosome $3 \mathrm{~B}$ ranged between one for ten loci [Xgpw7031-3B, Xwmc533-3B, Xwmc2743B, Xgpw2266-3B, Xgpw7805-3B, Xwmc418-3B, Xgpw 7467-3B, Хgpw 7586-3B, Хgpw7335-3B, $X g p w 5271-3 B]$ to 21 for locus Xgpw4431-3B. The PIC values ranged from 0 to 0.93 (mean 0.58 ) while SSR lengths varied from 12 to $156 \mathrm{bp}$. Analysis of the variation of allele numbers, PIC values and lengths of microsatellites showed that these traits varied along the chromosome 3B (Fig. 1, b). For allele number, it was high at the distal part of the short arm and then decreased slightly in the middle of the arm to increase again in the pericentromeric region. On the long arm, the allele number was low close to the pericentromeric region and in deletion bin 3BL7 $-0.63-1.00$ and increased close to and in deletion bin 3BL10 $-0.50-0.63$. PIC values and SSR length followed similar patterns except in bins 3BS9 - 0.57-0.78 and C-3BL10 - 0.50 (white arrows on Fig. 1,b), where the PIC values were higher and in bin $\mathrm{C}-3 \mathrm{BS} 1-0.33$ where the length was lower. Similarly to chromosome $3 \mathrm{~A}$, the diagram of moving correlation between the SSR lengths and allele numbers was built (Fig. 2, b). The correlation between these two traits was very high $(>0.5)$ on the short arm and in the pericentromeric region of the long arm. Then it decreased abruptly in the middle of the long arm and reached a minimum $(-0.374)$. This was due to the data from locus Xgpw7467-3B and removing of this locus from the set of data changed the reduction of correlation from 0.9 to only 0.2 (data not shown). There was a general trend of correlation to increase from the centromere toward the telomere on both chromosome arms.
Variability of microsatellite loci along chromosome $3 D$. We analyzed the variation of PIC values, microsatellite lengths and allele numbers along the chromosome 3D (Fig. 1, c). Between five and 19 SSR loci were assigned to the four deletion bins of chromosome 3D (Table 4). Allele number for the $48 \mathrm{SSR}$ loci assigned to chromosome 3D ranged from one for the three loci Xgpw1062-3D, Xgpw2266-3D and Xgpw8116-3D to 20 for locus $X c f d 9-3 D$. PIC values ranged from 0 to 0.93 (mean 0.54) while SSR length varied from 12 to $156 \mathrm{bp}$. SSR lengths did not vary much along the short arm but they were a little higher on the long arm. On the contrary, PIC values and allele numbers were similarly higher in short arm and in bin 3DL3 $0.81-1.00$ (white arrows on Fig. 1,c). The diagram of moving correlation between SSR lengths and allele numbers was built (Fig. 2,c) and showed that the correlation increased considerably from the centromere toward the telomere of the short arm while on the contrary, there was almost no correlation on chromosome arm 3DL. In particular, the correlation was very high for the middle of the short arm (up to 0.8 ). In contrast, close to the centromere, the correlation equaled zero and remained weak on the rest of the long arm (mean $r=0.2$ ).

Comparative analysis between homoeologous group 3 chromosomes. A comparative analysis of allele number, SSR length and PIC values between the three chromosomes from homoeologous group 3 reveals that each chromosome had unique pattern for the curves and we had not detect clear increasing of the allele numbers or SSR lengths with the distance from the centromere towards the distal part of chromosomes as we initially expected (see Fig. 1). Such a tendency was only slightly observed for the long arm of chromosome 3D. Concerning the correlations between SSR length and allele number, it increased from the pericentromeric region toward the telomeres and coefficients of correlations between SSR length and allele num- 

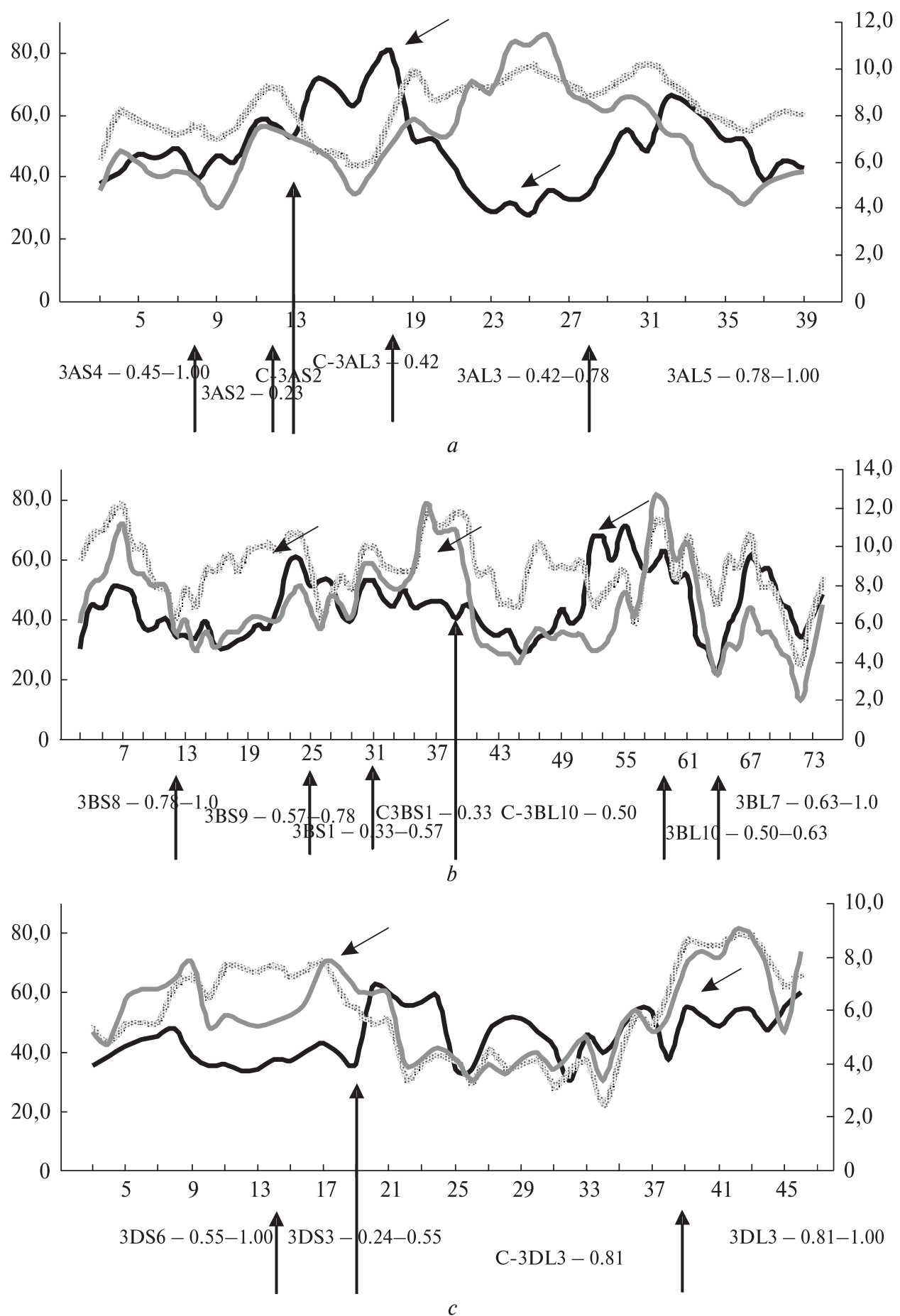

Fig. 1. Variability of allele number (grey curve), length (black curve) and PIC $\times 100$ value (dotted curve) of microsatellites using the method of moving means (5 points) along chromosomes from homoeologous group 3 ( $a$ - chromosome $3 \mathrm{~A}$; $b-$ chromosome 3B; $c$ - chromosome 3D). Approximate position of the centromere is indicated with the long black arrow. X-axis: microsatellite loci numbers (according to Table 2-4) along the chromosomes. Telomeric regions of the short arms are on the left and the one of the long arms are on the right. Y-axis: left - length of microsatellite in bp and PIC value $\times 100$; right - allele number. Important points as discussed in the text are indicated with white arrows 


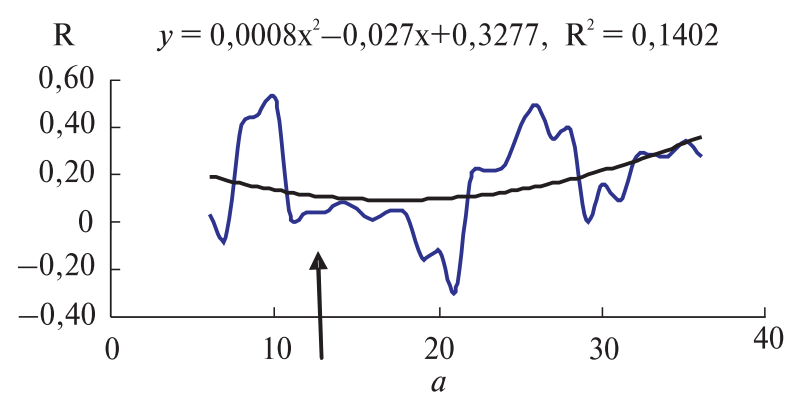

$y=0,0003 \mathrm{x}^{2}-0,0292 \mathrm{x}+1,099, \mathrm{R}^{2}=0,2738$

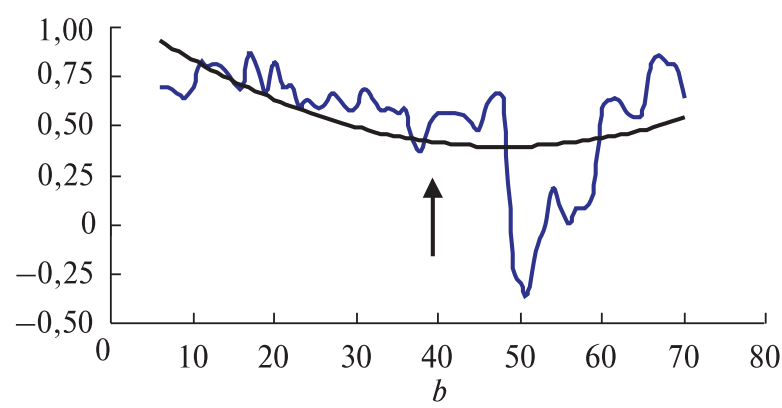

$y=0,0007 \mathrm{x}^{2}-0,0443 \mathrm{x}+0,8438, \mathrm{R}^{2}=0,2231$

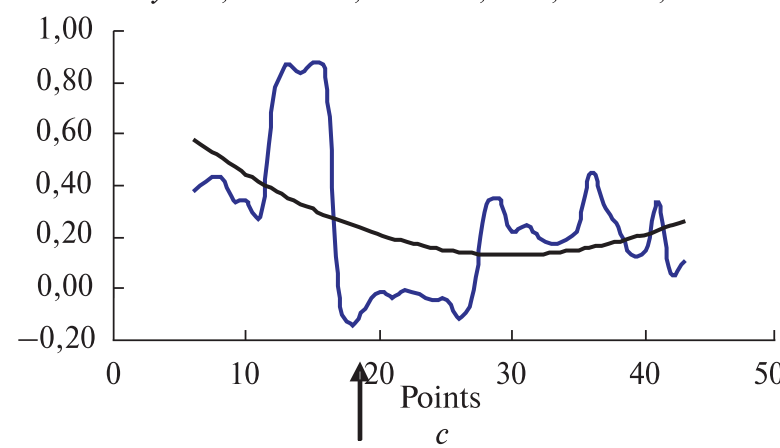

Fig. 2. Moving correlation (11 points) between allele number and microsatellite length along chromosomes from homoeologous group 3 ( $a$ - chromosome $3 \mathrm{~A} ; b-$ chromosome $3 \mathrm{~B} ; c$ - chromosome $3 \mathrm{D}$ ) and general trend of variation tested along. $\mathrm{X}$-axis: microsatellite loci number (according to Table 2-4) along the chromosomes. Approximate position of the centromere is indicated with an arrow. Telomeric short arm regions are on the left and long arms regions are on the right. Y-axis: correlation coefficients between allele number and the length of microsatellites

ber were higher on short arms of $3 \mathrm{~B}$ and $3 \mathrm{D}$ chromosomes than on the long arms.

Discussion. It has been demonstrated that microsatellites are powerful molecular markers in wheat because of the high degree of polymorphism they reveal $[4,43]$ and also because of their high locus specificity compared to RFLP markers [8, $39,44]$. Thus, they constitute a major tool for establishing genetic variability in wheat collections $[1,2,45]$. Here, we used 165 microsatellites from wheat homoeologous group 3 in order to evaluate the variation of the genetic variability at the chromosome level and to compare the results according to the type and length of motifs as well as between the homoeologous chromosomes. We focused our attention on homoeologous group 3 chromosomes because this group has been retained as a model for the establishment of a physical map of the wheat genome prior to large scale sequencing by the International Wheat Genome Sequencing Consortium (IWGSC; http://www.wheatgenome.org).

Concerning the type and length of the microsatellite motifs, the dinucleotide motifs and especially $(\mathrm{GA})_{n}$ and $(\mathrm{CA})_{n}$ repeats appeared to be more abundant in our investigations. No enrichment was observed for microsatellites like $(\mathrm{GC})_{n}$ or $(\mathrm{AT})_{n}$, although (AT) microsatellites are very abundant in plants [46-48].

This was expected since these two latter motifs are rarely selected in enrichment or screening techniques [49, 3, 50]. Moreover, because of the complementarities of the motif bases at the level of double strand DNA, these SSRs are making a hairpin, which makes them difficult to isolate [49, 50]. However, from data obtained from random sequencing (11 Mb from $\mathrm{BAC}$ end sequences from chromosome 3B [51]), the most likely distribution of microsatellite motifs within the wheat genome was very different from that obtained from enriched library. Particularly, microsatellites with tri- and tetra-nucleotidic motifs were more abundant compared to enriched libraries [51], as are some of them with particular motifs (like AT) which are almost impossible to recover by specific enrichment.

We found that the average number of alleles varied according to the type of motif. The dinucleotide repeats have more alleles than the tri-, tetra- and pentanucleotide repeats which was in accordance to the literature. According to Chakraborty et al. [52], the dinucleotide motifs display a higher mutation rate than the trinucleotide motifs which in turn show a higher rate than the tetranucleotide motifs.

Moreover, Lee et al. [53] confirmed that tetranucleotide repeats are considerably more stable than dinucleotide repeats and in yeast, it was shown that microsatellites with smaller repeat 
units are much less stable than those with larger repeat units [54]. In addition, the number of repeats could account for some differences in mutation frequencies. Microsatellites with large numbers of repeats are generally more polymorphic than shorter tracts [55-57].

It has long been known that the level of polymorphism is quite different between the three genomes, the B genome being the most polymorphic while the $\mathrm{D}$ genome is generally the less polymorphic [58]. Considering this, we expected variability to be lower on this latter chromosome compared to the other two.

This was actually the case since allele number per locus (6.04) as well as mean PIC values (0.54) for chromosome $3 \mathrm{D}$ were smaller compared to chromosome 3A (6.73 allele number / locus and 0.61 PIC values) and 3B (6.89 allele number / locus and 0.58 PIC values) chromosomes, but the differences were not statistically significant (Mann-Whitney U-test, $p>0.05$ ). However, the behaviour of the correlations between SSR length and allele number along homoeologous group 3 chromosomes were increased from the centromere toward the telomere, especially for the short arms of $3 \mathrm{~B}$ and $3 \mathrm{D}$ chromosomes.

We did not reveal the increasing of lengths of microsatellites with distance from centromer. For example, the average length of SSRs that located on distal bin 3AL5 - 0.78-1.00 was 50.6 bp and for microsatellites assigned to more proximal bin 3AL3 - 0.42-0.78 average length was $40.4 \mathrm{bp}$, but difference was not statistically significant. The average lengths of SSRs that have been mapped on bins 3BS $8-0.78-1.0$ and 3BS9 $-0.57-0.78$ were similar $38.5 \mathrm{bp}$ and $38.9 \mathrm{bp}$, respectively. The same situation we found for microsatellites on distal bin $3 \mathrm{BL} 7-0.63-1.0$ and on more proximal region of long arm 3B chromosome (C-3BL10-0.50), where the average lengths were 45.1 and $44.1 \mathrm{bp}$, respectively.

Difference between average of lengths of SSRs located on proximal bins C-3DL3 - 0.81 (45.7 bp) and distal bin 3DL3 - 0.81-1.00 (54.2 bp) also was not statistically significant.

We did not find statistically significant differences in allele numbers and PIC values for SSRs located on more distal bins on $3 \mathrm{~A}$ and $3 \mathrm{~B}$ chromosomes. On 3D we tested significant differences (Mann-Whitney U-test, $\mathrm{p}<0.05$ ) between the
PIC values determined for SSRs assigned to 3DL3 $0.81-1.0$ bin that is distal compare to the more proximal C-3DL3 -0.81 bin. Average PIC values on these two comparing regions were 0.71 (3DL3 $0.81-1.0)$ and 0.37 (C-3DL3 - 0.81). Analysis of allele numbers of SSRs assigned to the regions, which we have described above (3DL3 - 0.811.0 vs C-3DL3 - 0.81) revealed average allele numbers per locus 8.1 and 4.4 respectively, differences were significant $(p<0.05)$.

It is well known that each chromosome of wheat has a unique pattern of recombination rate [59]. In general, recombination is strongly reduced in the pericentromeric regions of chromosomes contrary to the telomeric regions where it is high. In wheat, local recombination rate is positively correlated with physical distance from the centromere [12]. According to these authors, microsatellite loci located in distal regions with presumably high recombination rates show longer allele size and more polymorphism than loci located in proximal regions. Similarly, Huang et al. [60] found a positive correlation between the genetic distance from centromere and the number of alleles per microsatellite locus in hexaploid wheat.

However, Huang et al. [60] used genetic distances as reference, while in some cases, there are huge differences between genetic and physical distances; it is thus possible that the SSRs they tested were located in the same deletion bin in the telomeric region. In our study it was possible to choose microsatellites located in more centromeric regions because SSRs were assigned to deletion bins using deletion lines.

According to our results, we can conclude that the genetic variability of SSR loci on homoeologous group 3 chromosomes varied along the chromosomes. However, the variability at distal regions was not as extended as expected, which suggests that recombination which occurs more frequently in the distal part of the chromosomes does not significantly contribute to the extension of the variability of the microsatellite loci. SSR distributions are associated with sites of recombination, most probably as a consequence of repetitive sequences being involved in recombination rather than being a consequence of it [61, 62]. SSR genetic variability is thus probably due to other phenomena such as the model for SSR mutation based on replication slippage previously formulated by Levinson et 
al. [63]. Replication slippage or slipped strand mispairing refers to the out-of-register alignment of the two DNA strands following dissociation at the time when the DNA polymerase traverses the repetitive region. This slippage implies the formation of a single-strand loop during DNA synthesis and addition (or suppression, depending on the strand concerned with the loop) of a motif. Most of these primary mutations are corrected by the mismatch repair system, and only the small fraction that is not repaired ends up as microsatellite mutation events [64]. This model, which can be applied in distal as well as in proximal chromosome parts, is thus probably favoured compared to unequal recombination for evolution of SSR variability in wheat.

The support of Egide (Econet $08113 Z$ G programme) and INRA for the grant of SC is greatly acknowledged. The authors gratefully thank Georges Gay and Alain Loussert for growing the plants. The genotyping platform GENTYANE is also greatly acknowledged for its help in managing the robotics, Alexander Khokhlov for discussing results and Sylvie Bernard for her contribution in improving this manuscript.

\section{С. Чеботарь, П. Сурдий, Э. По, Ф. Бальфурье, К. Фёйе, М. Бернар \\ ИССЛЕДОВАНИЕ ГЕНЕТИЧЕСКОЙ ВАРИАБЕЛЬНОСТИ МИКРОСАТЕЛЛИТНЫХ ЛОКУСОВ ТРЕТЬЕЙ \\ ГОМЕОЛОГИЧНОЙ ГРУППЫ ХРОМОСОМ МЯГКОЙ ПШЕНИЦЫ}

Изучали вариабельность МС-локусов третьей гомеологичной группы хромосом $T$. aestivum L., осуществили сопоставление изменчивости микросателлитов в дистальных и проксимальных областях хромосом и физическое картирование МС-локусов с помощью делеционных, дителосомных, нуллитетрасомных линий и провели сравнительный анализ вариабельности микросателлитных локусов хромосом 3A, 3B и 3D. Физически картировано 165 микросателлитов на хромосомах третьей гомеологичной группы T. aestivum L. Выполненные исследования вносят существенный вклад в насыщение физических карт 3A, 3В и 3D хромосом МC-маркерами. Характер варьирования числа аллелей МС и их длины на всей протяженности исследованных хромосом главным образом нерегулярен. Не выявили статистически значимых достоверных различий по количеству аллелей, значениям PIC или длине МС-локусов для микросателлитов, локализованных на хромосомах 3А, 3В и 3D мягкой пшеницы.

$$
\begin{gathered}
\text { С. Чеботар, П. Сурдій, Е. По, Ф. Бальфур'є, } \\
\text { К. Фьойє, М. Бернар }
\end{gathered}
$$

ДОСЛІДЖЕННЯ ГЕНЕТИЧНОЇ ВАРІАБЕЛЬНОСТІ МІКРОСАТЕЛІТНИХ ЛОКУСІВ ТРЕТЬОЇ
ГОМЕОЛОГІЧНОЇ ГРУПИ ХРОМОСОМ
М'ЯКОЇ ПШЕНИЦІ

Вивчали варіабельність МС-локусів третьої гомеологічної групи хромосом $T$. aestivum L., здійснили порівняння мінливості мікросателітів у дистальних та проксимальних областях хромосом, а також фізичне картування МС-локусів за допомогою делеційних, дітелосомних, нулітетрасомних ліній та провели порівняльний аналіз варіабельності мікросателітних локусів хромосом 3A, 3B і 3D. Фізично картовано 165 мікросателітів на хромосомах третьої гомеологічної групи T. aestivum L. Виконані дослідження є істотним внеском у насичення фізичних карт хромосом 3A, 3B i 3D MC-маркерами. Характер варіювання числа алелів MC та їх довжини по всій довжині досліджених хромосом головним чином нерегулярний. Не виявлено статистично значущих достовірних відмінностей за кількістю алелів, значенням PIC та довжині МС-локусів для мікросателітів, локалізованих на хромосомах 3А, 3В і 3D м'якої пшениці.

\section{REFERENCES}

1. Roussel V., Koenig J., Beckert M et al. Molecular diversity in French bread wheat accessions related to temporal trends and breeding programmes // Theor. Appl. Genet. - 2004. - 108. - P. 920-930.

2. Roussel V., Leisova L., Exbrayat F. et al. SSR allelic diversity changes in 480 European bread wheat varieties released from 1840 to 2000 // Theor. Appl. Genet. 2005. - 111. - P. 162-170.

3. Röder M.S., Plaschke J., König S.U. et al. Abundance, variability and chromosomal location of miscrosatellites in wheat // Mol. Gen. Genet. - 1995. - 246. - P. 327333.

4. Röder M.S., Korzun V., Wandehake K. et al. A microsatellite map of wheat // Genetics. - 1998. - 149. P. 2007-2023.

5. Bryan G.J., Collins A.J., Stephenson P. et al. Isolation and characterization of microsatellites from hexaploid bread wheat // Theor. Appl. Genet. - 1997. - 94. - P. 557563.

6. Pestsova E., Ganal M.W., Röder M.S. Isolation and mapping of microsatellite markers specific for the D genome of bread wheat // Genome. - 2000. - 43. P. 689-697.

7. Gupta P., Balyan H., Edwards K. et al. Genetic mapping of 66 new microsatellite (SSR) loci in bread wheat // Theor. Appl. Genet. - 2002. - 105. - P. 413-422.

8. Guyomarcrh H., Sourdille P., Edwards K.J. et al. Studies of the transferability of microsatellites derived from 
Triticum tauschii to hexaploid wheat and to diploid related species using amplification, hybridization and sequence comparisons // Theor. Appl. Genet. - 2002. 105. - P. 736-744.

9. Somers D.J., Isaac P. Edwards K.J. A high-density microsatellite consensus map for bread wheat (Triticum aestivum L.) // Theor. Appl. Genet. - 2004. - 109. - P. 1105-1114.

10. Schmidt T., Heslop-Harrison J.S. The physical and genomic organization of miscrosatellites in sugar beet // Proc. Natl. Acad. Sci. USA. - 1996. - 93. - P. 87618765.

11. Cuadrado A., Schwarzacher T., Jouve N. Identification of different chromatin classes in wheat using in situ hybridization with simple sequence repeat oligonucleotides // Theor. Appl. Genet. - 2000. - 101. - P. 711717.

12. Thuillet A.C., Bataillon T., Sourdille P. et al. Factors affecting polymorphism at microsatellite loci in bread wheat [Triticum aestivum (L. Thell]: effects of mutation processes and physical distance from the centromere // Theor. Appl. Genet. - 2004. - 108. - P. 368-377.

13. Janda J., Bartos J., Kubalakova M. et al. Construction of a subgenomic BAC library specific for chromosomes 1D, 4D, and 6D of hexaploid wheat // Theor. Appl. Genet. - 2004. - 109. - P. 1337-1345.

14. Janda J., Safar J., Kubalakova M. et al. Novel resources for plant genomics: BAC library specific for the short arm of wheat chromosome 1B // Plant J. - 2006. - 47. P. 977-986.

15. Safar J., Bartos J., Janada J. et al. Dissecting large complex genomes: flow sorting and BAC cloning of individual chromosomes from bread wheat // Plant J. 2004. - 39. - P. 960-968.

16. Paux E., Sourdille P., Salse J. et al. A physical map of the $1 \mathrm{~Gb}$ bread wheat chromosome $3 \mathrm{~B} / /$ Science 2008. - 322 (5898). - P. 101-104.

17. Gill B.S., Friebe B., Endo T.R. Standard karyotype and nomenclature system description of chromosome bands and structural aberrations in wheat (Triticum aestivum) // Genome. - 1991. - 34. - P. 830-839.

18. Bennett M.D., Smith J.B. Nuclear DNA amounts in angiosperms // Proc. R. Soc. Lond. B. - 1991. - 334. P. 309-345.

19. Badaeva E.D. Evolution of genomes of wheats and their wild relatives: molecular-cytogenetics investigations // Thesis of habilitation work. - Moskow, 2000. - $48 \mathrm{p}$.

20. Gill K.S., Gill B.S., Endo T.R. A chromosome regionspecific mapping strategy reveals gene-rich telomeric ends in wheat // Chromosoma. - 1993. - 102. - P. 374 381 .

21. Lukaszewski A.J., Curtis C.A. Physical distribution of recombination in B-genome chromosomes of tetraploid wheat // Theor. Appl. Genet. - 1993. - 85. - P. 121127.

22. Moore G. Cereal chromosome structure, evolution, and pairing // Annu. Rev. Plant Physiol. - 2000. - 51. P. 195-222.

23. Munkvold J.D., Greene R.A., Bermudez-Kandianis C.E. et al. Group 3 chromosome bin maps of wheat and their relationship to rice chromosome $1 / /$ Genetics. 2004. - 168. - P. 639-650.

24. Anderson J.A., Stack R.W., Liu S. et al. DNA markers for Fusarium head blight resistance QTLs in two wheat populations // Theor. Appl. Genet. - 2001. - 102. P. 1164-1168.

25. Bai G., Kolb F.L., Shaner G. et al. Amplified fragment length polymorphism markers linked to a major quantitative trait locus controlling scab resistance in wheat // Phytopathology. - 1999. - 89. - P. 343-348.

26. Khlestkina E.K., Röder M.S., Uger O. et al. Fine mapping and origin of gene for non-specific adult plant resistance against strip rust (Puccinia striiformis) in wheat // EWAC News Letters. - JIC, Norwich, 2002. P. $111-113$.

27. Kulwal P.L., Singh R., Balyan H.S. et al. Genetic basis of pre-harvest sprouting tolerance using single-locus and two-locus QTL analyses in bread wheat // Funct. Integr. Genom. - 2004. - 4. - P. 94-101.

28. McIntosh R.A., Devos K.M., Dubcovsky J. et al. (2007) http: // www.shigen.nig.ac.jp /wheat/komugi /genes/ symbol

29. Ravel C., Praud S., Canaguier A. et al. DNA sequence polymorphism and their application in bread wheat // Genetic variation for plant breeding. - Eucarpia, Tulln, 2004. - P. 177 - 181

30. Haseneyer G., Ravel C., Dardevet M. et al. High level of conservation between genes coding for the GAMYB transcription factor in barley (Hordeum vulgare L.) and bread wheat (Triticum aestivum L.) collections // Theor. Appl. Genet. - 2008. - 117(3). - P. 321-331.

31. Sears E.R. The aneuploids of common wheat // Mo. Agric. Exp. Sta. Res. Bull. - 1954. - 572. - P. 1-58.

32. Sears E.R. Nullisomic-tetrasomic combinations in hexaploid wheat // Chromosome manipulation and plant genetics. - London : Oliver and Boy Press, 1966. P. $29-45$.

33. Endo T.R., Gill B.S. The deletion stocks of common wheat // J. Heredity. - 1996. - 87. - P. 295-307.

34. Tixier M.H., Sourdille P., Charmet G. et al. Detection of QTLs for crossability in wheat using a doubled-haploid population // Theor. Appl. Genet. - 1998. - 97. P. 1076-1082.

35. http://wheat.pw.usda.gov/ggpages/SSRclub/Genetic Physical/

36. Nicot N., Chiquet V., Gandon B. et al. Study of simple sequence repeat (SSR) markers from wheat expressed sequence tags (ESTs) // Theor. Appl. Genet. - 2004. 109. - P. 800-805.

37. Botstein D., White R.L., Skolnick M. Construction of a genetic linkage map in man using restriction fragment 
length polymorphisms // Amer. J. Hum. Genet. 1980. - 32, № 3. - P. 314-331.

38. Tukey J.W. Exploratory data analysis. - Moskow : Mir, 1981. $-688 \mathrm{p}$.

39. STATISTIKA 6 for Windows -http://www.statsoft.ru

40. Guyomarcrh H., Sourdille P., Charmet G. et al. Characterisation of polymorphic microsatellite markers from Aegilops tauschii and transferability to the D-genome of bread wheat // Theor. Appl. Genet. - 2002. - 104. P. 1164-1172.

41. Sourdille P., Singh S., Cadalen T. et al. Microsatellitebased deletion mapping system for the establishment of genetic map - physical map relationships in wheat // Funct. Integr. Genom. - 2004. - 4. - P. 12-25.

42. Goyal A., Bandopadhyay R., Sourdille P. et al. Physical molecular maps of wheat chromosomes // Funct. Integr. Genom. - 2005. - 5. - P. 260-263.

43. Stephenson P., Bryan G., Kirby J. et al. Fifty new microsatellite loci for the wheat genetic map // Theor. Appl. Genet. - 1998. - 97. - P. 946-949.

44. Sourdille P., Tavaud M., Charmet G. et al. Transferability of wheat microsatellites to diploid Triticeae species carrying the A, B, and D genome // Theor. Appl. Genet. - 2001. - 103. - P. 346-352.

45. Balfourier F., Roussel V., Strelchenko P. et al. A worldwide bread wheat core-collection arrayed in a 384-well plate // Theor. Appl. Genet. - 2007. - 114. - P. 1265-1275.

46. Lagercrantz U., Ellegren H., Andersson L. The abundance of various polymorphic microsatellite motifs differs between plants and vertebrates // Nucl. Acids Res. 1993. - 21. - P. 1111-1115.

47. Morgante M., Olivieri A.M. PCR-amplified microsatellites as markers in plant genetics // Plant J. - 1993. 3. - P. 175-182.

48. Wang Z., Weber G.L., Zhong G. et al. Survey of plant short tandem DNA repeats // Theor. Appl. Genet. 1994. - 88. - P. 1-6.

49. Östrander E.A., Jong P.M., Rine J. et al. Construction of small-insert genomic DNA libraries highly enriched for microsatellite repeat sequences // Proc. Nat. Acad. Sci. USA. - 1992. - 89. - P. 3419-3423.

50. Edwards K.J., Barker J.H.A., Daly A. et al. Microsatellite libraries enriched for several microsatellite sequences in plants // Biotechniques. - 1996. - 20. - P. 758 760.

51. Paux E., Roger D., Badaeva E. et al. BAC-end sequencing from sorted chromosome in polyploids: an efficient way of understanding genome composition and evolution and developing chromosome-specific markers for genetic and physical mapping // Plant J. - 2006. - 48. P. 463-474.
52. Chakraborty R., Kimmel M., Stivers D.N. et al. Relative mutation rates at di-, tri-, and tetranucleotide microsatellite loci // Proc. Nat. Acad. Sci. USA. - 1997. 94. - P. 1041-1046.

53. Lee J.S., Hanford M.G., Genova J.L. et al. Relative stabilities of dinucleotide and tetranucleotide repeats in cultured mammalian cells // Human Mol. Genet. 1999. - 8. - P. 2567-2572.

54. Sia E.K., Kokoska R.J., Dominska M. et al. Microsatellite instability in yeast: dependence on repeat unit size and DNA mismatch repair genes // Mol. Cell Biol. 1997. - 17. - P. 2851-2858.

55. Weber J.L. Informativeness of human $(\mathrm{dC}-\mathrm{dA})_{n} \cdot(\mathrm{dG}-$ $\mathrm{dT})_{n}$ polymorphism // Genomics. - 1990. - 7. - P. 524530.

56. Hudson T.J., Engelstein M., Lee M.K. et al. Isolation and chromosomal assignment of 100 highly informative human simple sequence repeat polymorphisms // Genomics. - 1992. - 13. - P. 622-629.

57. Wierdl M., Dominska M., Petes T.D. Microsatellite instability in yeast: dependence on the length of the microsatellite // Genetics. - 1997. - 146. - P. 769779.

58. Chao S., Sharp P.J., Worland A.J. et al. RFLP-based genetic maps of wheat homoeologous group 7 chromosomes // Theor. Appl. Genet. - 1989. - 78. - P. 495504.

59. Boyko E., Kalendar R., Korzun V. et al. A high-density cytogenetic map of the Aegilops tauschii genome incorporating retrotransposons and defense-related genes: insights into cereal chromosome structure and function // Plant Mol. Biol. - 2002. - 48. - P. 767-790.

60. Huang X.Q., Börner A., Röder M. et al. Assessing genetic diversity of wheat (Triticum aestivum L.) germplasm using microsatellite markers // Theor. Appl. Genet. 2002. - 105. - P. 699-707.

61. Treco D., Arnheim N. The evolutionarily conserved repetitive sequence $\mathrm{d}$ (TG.AC) $\mathrm{n}$ promotes reciprocal exchange and generates unusual recombinant tetrads during yeast meiosis // Mol. Cell. Biol. - 1986. - 6. P. 3934-3947.

62. Majewski J., Ott J. GT repeats are associated with recombination on human chromosome 22 // Genome Res. - 2000. - 10. - P. 1108-1114.

63. Levinson G., Gutman G.A. Slipped-strand mispairing: a major mechanism for DNA sequence evolution // Mol. Biol. Evol. - 1987. - 4. - P. 203-221.

64. Schlötterer C., Tautz D. Slippage synthesis of simple sequence DNA // Nucl. Acids Res. - 1992. - 20. P. 211-215.

Received 09.10.08 